ELORE (ISSN 1456-3010), vol. 19 - 2/2012.

Julkaisija: Suomen Kansantietouden Tutkijain Seura ry.

[http://www.elore.fi/arkisto/2_12/salmi-niklander.pdf]

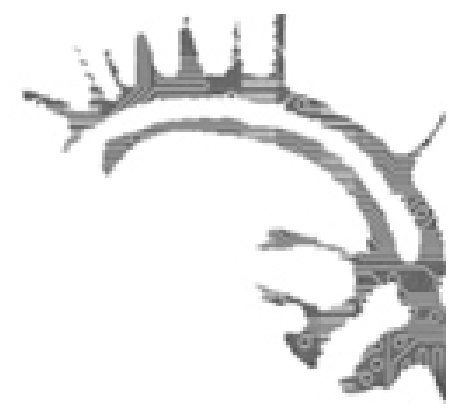

\title{
KIRJA-ARVIO
}

\section{KOTIVARKAUS NAISTEN ASEMAA KOSKEVAN JULKISEN KESKUSTELUN SYTYTTÄJÄNÄ}

STARK, LAURA 2011: The Limits of Patriarchy. How Female Networks of Pilfering and Gossip Sparked the First Debates on Rural Gender Rights in the $19^{\text {th }}$-Century FinnishLanguage Press. Studia Fennica Ethnologica 13. Helsinki: Finnish Literature Society. 260 sivua.

\section{Kirsti Salmi-Niklander}

Kansalliskirjaston ylläpitämä Historiallinen sanomalehtikirjasto on erinomainen esimerkki niistä uusista mahdollisuuksista, joita historiallisten aineistojen digitoiminen tarjoaa tutkijoille. Aineistojen helpon saatavuuden lisäksi asiasanahaut mahdollistavat uudenlaisten tutkimuskysymysten etsimisen ja esittämisen. Laura Starkin tutkimus on folkloristiikan ja etnologian osalta ensimmäinen sanomalehtiaineistoja laajasti hyödyntävä tutkimus, jonka soisi innoittavan eri alojen tutkijoita näiden aineistojen hyödyntämiseen.

Starkin tutkimuksen tavoitteena on esittää uudenlaisia tulkintoja naisten ja miesten välisistä suhteista 1800-luvun Suomessa. Konkreettisena lähtökohtana on niin sanottu kotivarkaus, joka sytytti ensimmäisen naisen asemaa koskevan julkisen keskustelun 1860-luvun Suomessa. Kotivarkaus tarkoitti sitä, että maalaistalojen emännät ja tyttäret myivät maataloustuotteita isänniltä salaa ja hankkivat saaduilla tuloilla itselleen vaatteita ja kankaita. Tyttärien motiivina oli myötäjäisten kartuttaminen, emännät puolestaan halusivat näyttää sosiaalista asemaansa kulutustavaroiden avulla. 
Laura Stark rakentaa tutkimuksen teoreettisen kehyksen Christine Delphyn materiaalista patriarkaattia käsittelevistä tutkimuksista: Delphy näkee patriarkaatin ennemminkin taloudellisena kuin perhettä uusintavana ilmiönä, jossa vaimojen ( ja tytärten) palkaton työ tekee viljelystä taloudellisesti kannattavaa. Toinen keskeinen teoreettinen vaikuttaja teoksessa on James Scott, joka on tutkinut alistettujen ja valtaapitävien vuorovaikutusta toiminnan (agency) ja käytännön (practice) käsitteiden avulla. James Scottin keskeinen termejä ovat public transcript ja hidden transcript: julkisissa transkriptioissa valta- ja alistussuhteet ilmaistaan selvästi ja totuttujen keinojen avulla. Sekä vallanpitäjillä että alistetuilla ryhmillä on kuitenkin myös piilotettuja transkriptioita, joiden avulla voidaan vapautua alistussuhteiden normeista: alistetut voivat kapinoida ja valtaapitävät irrottautua roolistaan.

\section{JULKISUUDEN PELISÄÄNTÖJÄ OPPIMASSA}

Missä tilanteissa piilotetut transkriptiot voivat tulla julkisiksi ja miten niitä voidaan tutkia? Sanomalehtikirjoitukset ovat Starkin tutkimuksessa avainlähde näiden murrostilanteiden tutkimukseen. Sanomalehdet ovat Starkilla lähteen lisäksi myös tutkimuskohde: hän erittelee perusteellisesti lehtien toimituskäytäntöjä ja niitä syitä, joiden ansiosta maaseudun asukkaita, myös maalaisnaisia rekrytoitiin lehtien avustajiksi.

Yksi kotivarkauskeskustelun avainhenkilöistä oli kievarinpitäjän poika ja toimittaja Antti Manninen. Mannisen aloitteesta keskustelu kotivarkaudesta käynnistyi Tapiossa vuonna 1861, ja hän rekrytoi kirjoittajiksi myös nuoria maalaisnaisia. Tämä liittyi Mannisen naisten kasvatusta koskeviin ajatuksiin, jotka tuolloin olivat aikaansa edellä.

Uudet kirjoittajat eivät sopeutuneet kovin helposti julkisuuden pelisääntöihin, mistä toimittajat joutuivat heitä ojentamaan. Tyypillistä oli esimerkiksi useiden rinnakkaisten nimimerkkien käyttäminen, kun avustajat syystäkin pelkäsivät joutuvansa hankaluuksiin arvostellessaan paikallisia epäkohtia. Päätoimittajat olisivat mieluummin suoneet kirjoittajien esiintyvän omilla nimillään ja vaativat, että toimituksen tiedossa täytyi olla kirjoittajien oikeat nimet. Tähän oli juridisiakin perusteita, sillä päätoimittajat joutuivat itse vastuuseen loukkaavista kirjoituksista, mikäli kirjoittaja ei ollut tiedossa. Avustajien määrän kasvaessa toimittajat julkaisivat lehdissä kommentteja niille kirjoittajille, joiden tekstejä ei huolittu lehteen.

Laura Starkin kirja sisältää oikeastaan ainekset kahteen tutkimukseen, joista toinen käsittelee sanomalehdistön ja julkisuuden varhaisvaiheita, toinen taas patriarkaatin haastamista maaseudun perheissä. Tämä kaksinaisuus aiheuttaa jäsentelyyn rönsyilyä: alkulukuun on laadittu pitkä ja kiinnostava maalaisihmisten osallistumista 1800-luvun sanomalehtikirjoitteluun käsittelevä alaluku, joka sinänsä toimisi jo laajahkona artikkelina. Vasta tämän jälkeen päästään varsinaisen tutkimuksen aineistojen esittelyyn.

Sukupuolihistorian ohella Starkin tutkimus edustaa tutkimussuuntausta, jota voi luonnehtia historialliseksi mediaetnografiaksi. Mediaetnografian tutkimuskohteita ovat viestinnän ja julkisuuden muotojen vuorovaikutus, niihin liittyvät käytännöt ja muutosprosessit. Näitä voidaan tutkia yhtä hyvin tässä päivässä kuin historiassakin. 
Stark erittelee yksityiskohtaisesti kotivarkaus-debattia ja erityisesti nuorten naisten omaa osallistumista tähän keskusteluun. Stark erittelee kotivarkauskeskustelun diskursseja, jotka liittyvä ajan aatevirtauksiin: näissä diskursseissa nostettiin keskeiseksi tekijäksi joko uskonto, valtio, talo tai yksilö. Viides oli romanttinen diskurssi, jossa korostettiin moraalisia hyveitä. Suurin osa kirjoittajista suhtautui kielteisesti kotivarkauteen, mutta myös toisenlaisia ääniä esiintyi. Maria Loviisa Kukkonen nousi Antti Mannisen rohkaisemana puolustamaan Tapiossa muita nuoria maalaisnaisia: isäntien saituus sekä poikien ja tytärten epätasa-arvoisuus perinnönjaossa nostattivat tytöissä uhmaa, joka purkautui kotivarkautena.

Kotivarkaus-debatin diskurssianalyysi auttaa nostamaan esiin vivahteita patriarkaattikeskustelussa: vastakkain asettuvat valistunut ja valistumaton isäntä. Fennomaanisen sivistyneistön kirjoituksissa hahmottuva valistunut isäntä ymmärtää myös vaimonsa ja tytärtensä tarpeita ja antaa heille mahdollisuuksia kasvaa tulevan sukupolven valistuneiksi kasvattajiksi. Valistumaton isäntä puolestaan vieraannuttaa lapsensa itsestään kohtelemalla heitä töykeästi ja epätasa-arvoisesti. Stark löytää selityksiä myös sille, miksi juuri kotivarkaus nousi julkisen keskustelun kohteeksi. Ilmiössä yhdistyivät monet maaseudun murrosprosessit, ja kasvava kulutus teki kotivarkaudesta näkyvämmän ilmiön. Se nousi 1850-luvulla yksityisestä vaietusta toiminnasta julkisen keskustelun kohteeksi.

Kansatieteelliset kuvaukset ovat lehtikirjoitusten ohella tärkeintä tutkimusaineistoa teoksessa. Stark hyödyntää niitä erityisesti käsitellessään juoruja, jotka olivat kotivarkauden lisäksi merkittäviä naisten vallankäytön välineitä: niin sanotut kontinkantajat olivat kyläyhteisössä tärkeitä vaikuttajia, sillä he välittivät vanhemmille tietoa lasten puolisoehdokkaista. Stark erittelee oivaltavasti naisten juorujen merkityksiä maalaisyhteisöjen vallankäytössä. Tämä luku herättää kuitenkin kysymyksen: eivätkö huhut ja juorut olleet kuitenkin myös keskeinen osa miesten kulttuuria ja vallankäyttöä? Kuten Stark huomauttaa, huhuja ja juoruja on tutkittu paljon antropologian piirissä. Tämän keskustelun käsittely jää moniaineksisessa tutkimuksessa kuitenkin varsin vähäiseksi. Esimerkiksi Niko Besnier (2009) on tutkinut juoruja ja poliittista kulttuuria Nukualelen atollilla Polynesiassa. Hän arvostelee James Scottin edustamaa vastarintatutkimusta muistuttaen, että vallanpitäjät ja alistetut ovat vaikeasti määriteltäviä kategorioita.

\section{MITEN SUOMALAINEN KULTTUURI KÄÄNTYY ENGLANNIKSI?}

Englanninkielisenä Laura Starkin tutkimus on sekä suomalaisten tutkijoiden että kansainvälisen lukijayleisön ulottuvilla. Aihepiiri kiinnostaisi varmasti myös laajempaa suomenkielistä lukijayleisöä, jolle tämä tutkimus tuskin kuitenkaan avautuu. Tutkimuksessa käytetään hyvin paljon pitkiä sitaatteja, joiden kääntämisessä tekijä on nähnyt paljon vaivaa. Sitaatit mahdollistavat sen, että lukija voi arvioida tulkintojen oikeutusta. Tässä tapauksessa sitaatit ovat kuitenkin jo tulkintoja alkuperäisestä aineistosta, sillä tekijä on kääntänyt ne itse englanniksi. Tiedän kokemuksesta, miten vaikeaa 1800-luvun ja 1900-luvun kielen, erityisesti oppimattomien kirjoittajien tekstien kääntäminen on, ja miten helposti nyanssit ja tekstien alkuperäinen karheus katoavat. Jotkut avainlauseet 
Kirsti Salmi-Niklander: Kotivarkaus naisten asemaa koskevan julkisen keskustelun sytyttäjänä

on sentään julkaistu myös alkukielellä: esimerkiksi Maria Loviisa Kukkosen kirjoituksen uhmakas repliikki: "Koska ette anna, niin minä otan niin että piisaa!"

Antropologisessa ja folkloristisessa tutkimuksessa on yleinen käytäntö, että sitaatit julkaistaan sekä alkukielellä että tutkimuksen kielellä. Monet sitaattien alkuperäislähteistä ovat hankalasti saatavilla, joten lukija ei pääse kovin helposti tarkistamaan niitä. Olisi myös syytä pohtia sitä, riittääkö etnologin ammattitaito kaunokirjallisten tekstien kääntämiseen. Lukijaystävällisempi ratkaisu olisi tekstien referoiminen ja ydinkohtien siteeraaminen sekä englanniksi että suomeksi.

Jotkut Suomen historiaan liittyvät termit on käännetty epätäsmällisesti: youth clubs (s. 39) viitannee nuorisoseuroihin, mutta tämä ilmaisu antaa kovin epämääräisen kuvan näistä järjestöistä. Täsmällisempi englanninkielinen ilmaisu olisi agrarian youth society, vaikkei vastaavia järjestöjä ole ollut englanninkielisissä maissa. Kokonaisuutena Laura Starkin tutkimus tarjoaa kuitenkin rohkeita, monitieteisiä näkökulmia ja tutkimusaineistoon liittyviä aluevaltauksia. Sitaattien ja esimerkkien runsaus kertoo myös tutkijan innostuksesta aineistoonsa ja aiheeseensa.

\section{KirJallisuUs}

BESNIER, NIKO 2009: Gossip and the Everyday Production of Politics. Honolulu: University of Hawai'i Press.

Folkloristiikan dosentti Kirsti Salmi-Niklander toimii akatemiatutkijana Helsingin yliopistossa. 